Prof. dr. Sulejman Topoljak

\title{
LJUDSKA ISHRANA U SVJETLU ŠERIJATSKIH PROPISA I INTENCIJA
}

Sažetak

Ova studija elaborira jedno od esencijalnih ljudskih pitanja, pitanje filozofije ljudske ishrane u svjetlu islamski propisa i intencija. Studija je pokušala utvrditi da je islam univerzalni sistem ljudskog življenja potkrepljujući to činjenicom što njegove norme i propisi nisu zapostavili ni najmanji segment ljudskog života, potom se fokusirala na izvore ljudske ishrane, kako životinjskog tako i biljnog porijekla, detaljno ih nabrojila $i$ na svaku od njih se pravno osvrnula. Tokom studije je pojašnjen pravni status većine vrsta izvora hrane potkrijepljen relevantnim dokazima $i$ objektivnim odabirom najprihvatljivijeg mišljenja.

Studija je, također, gdje god je bilo moguće, pokušala ponuditi osnovna ili načelna pravila na osnovu kojih je moguće po islamu raspoznati dozvoljenu od zabranjene hrana. I na kraju, studija je došla do zaključka da je klasifikacija hrane u islamu na dozvoljenu $i$ nedozvoljenu prvenstveno pravo Zakonodavca iz proste činjenice što je On stvorio čovjeka i zbog toga On jedini najbolje zna koja je hrana za čovjeka najprikladnija i najkorisnija a koja je neprikladna i štetna.

Generalni zaključak do kojeg je studija došla je da se islamska filozofija ishrane pri klasifikaciji hrane na dozvoljenu i zabranjenu ne temelji a niti polazi isključivo od materijalne dobiti i biznisa, nego prvenstveno i samo od općeljudske koristi i zaštite i očuvanja ljudskog zdravlja i kosmičke harmonije čovjeka i prirode koja ga okružuje.

Uvod

Islam, kao univerzalni ljudski sistem vrijednosti, svojim propisima i normama obuhvatio je sve segmente ljudskog života. S obzirom da je hrana koja se unosi u ljudski organizam ključna stvar za život čovjeka, jer se od nje formira i nastaje ljudsko tijelo i zavisi zdravlje, islam je tom pitanju posvetio veliku pažnju. Pri normiranja ovog pitanja, on se povodio za svojom osnovnom filozofijom da su 
šerijatske norme i propisi samo sredstva putem kojih se pribavlja ljudima samo ono što je korisno i uklanja od njih samo ono što je štetno.

Sukladno tomu, islam je pri propisivanju i definiranju kulture ishrane svojim sljedbenicima uvažio tačno određenu filozofiju i metodologiju od koje, osim u nužnim situacijama, nije odstupao. Sve što je lijepo, korisno i dobro od hrane i pića dozvolo im je, a sve što je ogavno, ružno i štetno zabranio. Ovo esencijalno pravilo Kur'an je jasno i decidno proklamovao. Ono je univerzalno i sveobuhvatno i primjenjuje se na sve vrste i izvore hrane koja će se proizvesti i inovirati do Sudnjeg dana.

Cilj ove studije je da načelno elaborira vrste i izvore ishrane čije je konzumiranje po šerijatu dozvoljeno ili zabranjeno kako bi se sljedbenici islama, kao i oni koji se žele hraniti zdravom i korisnom hranom, upoznali sa izvorima zabranjene ljudske ishrane, tj. štetni za ljudsko zdravlje. Ova tematika je također i sa sociološko-humanog aspekta vrlo značajna i korisna.

$\mathrm{S}$ naučne strane bitna je zbog toga što joj se na našem govornom prostoru, a možda i šire, nije posvetila dovoljna pažnja koju zaslužuje. Sa sociološko-humane strane njena važnost proizilazi iz činjenice da je današnji čovjek izgubio ispravne parametre istinskih vrijednosti. Preferirao je materiju nad duhovnim i moralnim vrijednostima. Na taj način savremeni čovjek je u potpunosti materijaliziran. Materija je postala njegovim generatorom, ona ga pokreće i daje mu smisao i cilj života, a ne humanost i moralne vrijednosti. Savremeni čovjek svugdje, pa čak kada je i u pitanju ljudska ishrana, gleda samo na profit i zaradu. Dakle, filozofija savremene civilizacije i savremenog čovjeka jeste ostvarenje profita po svaku cijenu, profita i samo profita, a ne ostvarenje moralne čistoće, zaštite i očuvanja ljudskog zdravlja.

Zato će ovaj rad itekako dobro doći svima onima koji se ne slažu sa takvom filozofijom i kojima je stalo do njihova zdravlja.

\section{Izvori ishrane}

Izvori ljudske ishrane se mogu podijeliti na dvije osnovne kategorije: na ishranu životinjskog i ishranu biljnog porijekla. Životinje, kao osnovni izvor ljudske ishrane životinjskog porijekla, dijele se na vodene i kopnene, i u svakoj od tih kategorija životinja 
ima ih čije je meso dozvoljeno konzumirati, a ima i onih čije nije. Životinje čije se meso konzumira dijele se, pod jedan, na one: a) čije je meso dozvoljeno i b) čije je meso pokuđeno jesti; i, pod dva, na one: a) čije je meso dopušteno konzumirati pod uslovom da se kolju i b) čije meso nije dopušteno.

Kada govore o ovoj temi, islamski pravnici prvenstveno misle na sve životinje, i one koje je dozvoljeno jesti kao i one koje nije a ni u kom slučaju tu ne podrazumijevaju ljudsku vrstu jer je Uzvišeni sve na ovom svijetu stvorio radi čovjeka, a čovjeka je stvorio radi Sebe. Dakle, Allah je neke životinje stvorio radi ljudske ishrane a neke opet da ih čovjek koristi u druge svrhe radi čega su i stvorene. Čovjek je najodabranije stvorenje kojem je Uzvišeni sve podčinio u ovom kosmosu. Zbog toga se njegovo meso ne tretira u islamskom pravu kada se govori o ishrani i njenom pravnom statusu. Zabrana jedenja ljudskog mesa (kanibalizam) u islamu je općepoznata i islamski pravnici su se o tome eksplicite odredili kroz različitu islamsku pravnu literaturu. ${ }^{1}$ Ovo je ujedno i razlog zbog čega oni o kanibalizmu ne govore u poglavlju o ishrani nego u poglavlju o prijekoj nuždi (eddarure).

Islamski pravnici obično za zabranu konzumiranja mesa neke životinje upotrebljavaju sljedeće pravne termine: nije ga dozvoljeno jesti (la jehillu ekluhu), zabranjeno ga je jesti (juhrim ekluhu), ne konzumira se (la j'ukel), pokuđeno ga je jesti (jukrehu ekluhu). Hanefijski pravnici za većinu vrsta mesa čija zabrana nije utvrđena putem kategoričkih dokaza upotrebljavaju zadnji termin, tj. (jukrehu) aludirajući time na mekruh tahrim, tj. mekruh koji je blizak haramu a koji kod ostalih pravnika ima status harama.

Bitno je još istaći da su islamski pravnici saglasni o zabrani konzumiranja mesa samo jedne vrste životinja zbog toga što je utvrđena na kategoričan način. To je svinjsko meso. Kad su pak u pitanju ostale vrste, ne postoji takva saglasnost, nego među njima ovisno o vrsti životinja - postoje veća ili manja razilaženja. Konzumiranje mesa takvih životinja može biti zabranjeno (haram) ili pokuđeno na tahrim ili tenzih način, što će biti objašnjeno u ovoj studiji.

${ }^{1}$ Ibn-Abidin, Hašijetu Ibn-Abidin, 1/136; Derdir, Eš-Šerhu-s-sagir, 1/323; Remli, Nihajetu-1-muhtadž, 8/152; Rehibani, Matalibu uli-n-nuha, 6/323. 
Kada se govori o pravnom statusu hrane u islamu, treba istaći da se on ne tiče same hrane, nego i njena konzumiranja i upotrebe. Također ne postoji ni generalno pravno pravilo koje bi važilo za konzumiranje svih vrsta hrane. Zbog toga ćemo se u ovoj studiji osvrnuti na osnovne vrste hrane i navesti načelne propise.

Iz poglavlja koja tretiraju ovu tematiku primjećuje se da je u principu, po islamu, svaka hrana dozvoljena osim one za koju postoji poseban dokaz da je zabranjena. Ali i pored toga da se primijetiti da islam uvažava različite razloge zbog kojih je neka vrsta hrane zabranjena ili dozvoljena bez obzira kojeg porijekla bila. Načelno se može reći da se svi ti razlozi tiču općih šerijatskopravnih pravila i intencija koje imaju za cilj da što bolje i kvalitetnije uspostave i organizuju ljudski život na ovom svijetu.

Opći razlozi zbog kojih je po islamu zabranjeno konzumirati određene vrste hrane

Studioznim proučavanjem pravnih razloga ('ilela), koje islamski pravnici navode u vezi sa zabranom konzumiranja određene vrste hrane, može se konstatovati da je to zbog sljedećih razloga.

Prvi razlog: Štetnost

Pod ovim razlogom se prvenstveno misli na štetnost koja se reflektuje na ljudsko tijelo ili razum zbog konzumiranja određene vrste hrane. Pod ovaj razlog se mogu podvesti mnoge vrste hrane kao npr.:

a. Otrovna hrana životinjskog porijekla poput otrovnih riba, zmija, akrepa, pčela, stršljenova, ili otrovnih tvari koje se deriviraju iz njih, kao i otrovna hrana biljnog porijekla (neke otrovne biljke, gljive). Na zabranu tih stvari implicite ukazuju sljedeći dokazi: «I ne ubijajte se svojim rukama!» ${ }^{2}$ Poslanik, a.s., rekao je: «Ko uzme otrov pa se ubije, otrov će mu biti u ruci i pit će ga u džehennemskoj vatri u kojoj će zauvijek ostati.» ${ }^{3}$

\footnotetext{
${ }^{2}$ Kur'an, En-Nisa, 29.

${ }^{3}$ Bilježi ga Buharija, Fethu-1-Bari, 10/247.
} 
Treba istaći da malikijski i hanbelijski pravnici smatraju da su otrovne stvari i otrovi zabranjeni samo onima kojima štete. ${ }^{4}$ Ovakvo razmišljanje je sasvim logično i realno, jer mnogi lijekovi sadrže otrove u granicama u kojima ne štete ljudima, nego im koriste, liječe ih i u njihovim tijelima ubijaju mnoge štetne bakterije i viruse.

Pod ovaj razlog mogu se također ubrojati i sve stvari koje su štetne ali nisu otrovne. Kao primjer islamski pravnici navode zemlju, kamenje, ugalj itd. I ove stvari su zabranjene samo onima kojima i štete. Ovdje se mogu uvrstiti i sve životinje i biljke koje su štetne za ljudsko fizičko ili mentalno zdravlje ali u isto vrijeme nisu otrovne. Otrovnost i štetnost neke materije, biljke i životinje trebaju da odrede stručnjaci na osnovu znanja i iskustva.

\section{Drugi razlog: Opojnost, narkoza i omamljivanje}

$\mathrm{Na}$ osnovu ovog razloga zabranjuje se svaka hrana i piće koji opijaju razum bez obzira od čega su proizvedeni. Pod ovu vrstu hrane ubraja se i svaka vrsta opijuma i droge, koji utječu na ljudski um i tijelo i čine čovjeka ovisnim o njima.

Treći razlog: Nečistoća (en-nedžes).

Ovdje se ubrajaju nečiste $i$ onečišćene stvari čije se onečišćenje ne može tolerisati.

Kao primjer za onečišćene stvari može se navesti tečna hrana, npr. ulje, maslo i sl. ako se u njima nađe uginuli miš ili slično. Takva hrana se po šerijatu smatra nečistom i nije ju dozvoljeno konzumirati. Ako se ne radi o tečnoj hrani, onečišćenim će se smatrati samo ona koja se nađe neposredno oko tijela miša. Dakle, njegovim uklanjanjem ostatak hrane po šerijatu će se smatra čistim i dozvoljeno ju je koristiti.

Hanbelijski pravnici kao primjer za onečišćene stvari navode voće i povrće koje se zalijevalo ili gnojilo nečistim đubrivom. Takvi usjevi, po njima, smatraju se onečišćenim i zabranjeno ih je konzumirati. Dozvoljeno će ih biti koristiti tek onda kada se zaliju čistom vodom toliko puta koliko je potrebno da se ta nečistoća ukloni. Po drugom mišljenju hanbelijske pravne škole takvi usjevi su čisti i

${ }^{4}$ Derdir, Eš- ̌̌erhu-s-sagir, 2/183; Rehibani, Metalibu uli-n-nuha, 6/309. 
dozvoljeno ih je konzumirati jer se nečistoća pretvorila u čistu materiju kao što se i krv, koja je nečista, u utrobama muznih životinja pretvara u čisto mlijeko. ${ }^{5}$

Ovdje treba istaći da se stajsko đubrivo životinja čije je meso halal smatra čistim, pa prema tome gnojenje usjeva njime ne čini konzumiranje usjeva zabranjenim.

Hanefijski, malikijski i šafijski pravnici smatraju da usjevi koji se pognoje ili zaliju stajskim đubrivom, bez obzira od kojih životinja ono bilo, ne čini usjeve onečišćenim a niti zabranjenim (haram) za konzumiranje. ${ }^{6}$ Ovo mišljenje se preferira.

Četvrti razlog: Ogavnost kod ljudi zdrave prirode i rezona

Šafijski pravnici za ovaj razlog navode pljuvačku, hrakotinu, znoj i spermu. Sve ove tvari koje proisteknu od čovjeka smatraju se po šerijatu čistim, ali se zabranjuje njihovo konzumiranje radi ogavnosti. ${ }^{7}$ Hanbelijski pravnici kao ogavne navode balegu, mokraću, krpelje i vaši (uši) ${ }^{8}$

Hanbelijski pravnici smatraju da su balega i mokraća životinja čije se meso jede čiste, ali ih zbog ogavnosti nije dopušteno konzumirati, jer ogavnost ne isključuje čistoću. Dakle, svaka stvar koja je šerijatski čista ne znači da je i halal. ${ }^{9}$

\section{Peti razlog: Zabranjene stvari zbog tuđeg prava}

Kao primjer za ovaj razlog navodi se hrana koja nije u vlasništvu onoga koji je želi jesti, a niti se za to posjeduje dozvola od njenog vlasnika ili Zakonodavca (Allaha). Takav status ima svaka oteta ili ukradena hrana, ili hrana zarađena putem kocke, prostitucije ili ostalih po šerijatu nelegalnih sredstava. Imetak koji staratelj uzme iz imovine svog štićenika, ili nadzornik iz zadužbine na jedan uobičajen i ugovoren način, ili žena od svog muža, ako joj ne daje dovoljno za izdržavanje, ili ono što se uzme iz nužde, ne može se

\footnotetext{
${ }^{5}$ Ibn Kudame, El-Mugni, 11/82., El-Merdavi, El-Insaf, 10/368.

${ }^{6}$ Ibn Abidin, Hašijetu Ibn-Abidin, 5/217, Hirši, Hašijetu-1-Hirši, 1/88, Hejtemi, Tuhfetu-1-muhtadž, 8/149.

${ }^{7}$ Hejtemi, Tuhfetu-l-muhtadž, 8/148.

${ }^{8}$ Rehibani, Metalibu uli-n-nuha, 6309.

${ }^{9}$ Ibid.
} 
podvesti pod ovaj razlog zbog postojanja Zakonodavčeve dozvole koja im to omogućava i legalizuje.

Kad je riječ o nepostojanju Zakonodavčeve dozvole, i to onda kada se radi o životinjama čije je meso dozvoljeno konzumirati, većina islamskih pravnika pravi razliku između legalnosti klanja i zabrane samog čina. Npr. ako musliman ili kršćanin ukrade ili otme nečiju ovcu i zakolju je po šerijatu, njeno meso će biti dozvoljeno konzumirati ostalim ljudima, ali će se onaj koji je to učinio (kasap) smatrati, po šerijatu, prestupnikom zbog toga što je zaklao tuđu ovcu bez dozvole njena vlasnika i dozvole Zakonodavca. I zbog toga će on biti obavezan da kompenzira njenu vrijednost. Neki islamski pravnici smatraju da takvo meso neće biti dozvoljeno jesti ni kradljivcu a niti drugima ljudima zbog šerijatske zapreka koja se ogleda u postojanju tuđeg prava. ${ }^{10}$

\section{Hrana čije je konzumiranje po šerijatu pokuđeno (mekruh)}

Islamski pravnici ${ }^{11}$ su naveli nekoliko vrsta hrane koju je po šerijatu pokuđeno (mekruh) konzumirati:

a. Crveni i bijeli luk, prasa i slične biljke koje imaju neprijatan miris. Po islamu je takve biljke pokuđeno svježe konzumirati zbog njihova neprijatna mirisa, ali ne i nakon njegova neutraliziranja. Ako ih neko konzumira, pokuđeno mu je nakon toga otići u džamiju sve dok se njihov miris ne neutrališe. Poslanik, a.s., je rekao: «Ko jede bijeli luk, neka se udalji od nas, ili nek se udalji od naše džamije, i neka sjedi u svojoj kući.» ${ }^{12}$ Ahmed b. Ahmed je bio eksplicitan i rekao da je luk pokuđeno jesti zbog namaza.

b. Žitarice koje je gazio pitomi magarac ili mazga. Takve žitarice prije konzumiranja treba oprati pa ih tek onda jesti.

c. Voda iz bunara koji su u blizini mezarja ili druge nečistoće zbog postojanja mogućnosti da do vode dospije prljavština.

d. Svježe ili prijesno meso i meso koje se pokvarilo i usmrdjelo. Autor El-Ikna'a veli: «Hanbelijski pravnici smatraju da je

\footnotetext{
${ }^{10}$ Ibn Rušd, Bidajetu-l-mudžtehid, 1/452.

${ }^{11}$ Ibn Abidin, Hašijetu Ibn Abidin, 1/136, 139, 5/217; Hirši, Hašijtu-l-Hirši, 1/88; Hejtemi, Tuhfetu-l-muhtadž, 8/148-149; Rehibani, Metalibu uli-n-nuha, 6/308, 309, $315,317$.

12 Bilježi ga Buharija. Vidi: Fethu-l-Bari, 7/575 i Muslim, 1/394. I ovo je Muslimova verzija.
} 
konzumiranje spomenutih stvari pokuđeno, ali se preferira mišljenje da nije». ${ }^{13}$

\section{Vodene životinje}

Pod vodenim životinjama se misli na sve životinje koje žive u slatkovodnoj ili morskoj vodi, u rijekama, morima, jezerima, barama, morima i okeanima. O pitanju dozvoljenosti konzumiranja mesa vodenih životinja islamski pravnici imaju različite stavove. Pokušat ćemo ih ukratko u nastavku studije i elaborirati.

\section{Stav hanefijskih pravnika}

U osnovi, hanefijski mezheb od morskih životinja dozvoljava konzumiranje samo ribljeg mesa, tj. ribu svih vrsta. Postoje samo dvije vrste ribe oko kojih hanefijski pravnici nemaju iskristaliziran stav zbog toga što nisu načisto da li se te morske životinje ubrajaju u ribe ili u neku drugu vrstu. To su crna riba u obliku štita i jegulja.

Muhammed b. Hasan smatra da meso spomenutih dviju vrsta ribe nije dozvoljeno konzumirati. Međutim, oficijelno mišljenje mezheba je da je dozvoljeno jer se i one ubrajaju u ribu.

Hanefijski pravnici zabranjuju konzumiranje mesa plutajuće ribe, tj. ribe koja je uginula prirodnom smrću (et-tafi) zbog postojanje mogućnosti da je uginula od neke opake bolesti, ${ }^{15}$ dok se riba koja ugine od poznatog uzroka ne razlikuje od one koja se ulovi i umre nakon što se izvadi iz vode. U slučaju kada riba proguta ribu, progutanu ribu je po mišljenju hanefijski pravnika dozvoljeno jesti, jer je uginula zbog poznatog razloga, tj. gutanja. A ako ugine zbog vrućine, hladnoće ili nedostatka vode, o konzumiranju takve ribe hanefijski pravnici imaju dva stava.

Po prvom stavu meso takve ribe nije dozvoljeno konzumirati zbog toga što navedena tri razloga obično ne uzrokuju pomor ribe. Dakle, postoji mogućnost da je takva riba uginula prirodnom smrću.

\footnotetext{
${ }^{13}$ Ovdje treba istači da se pod usmrdjelim mesom misli na meso koje se tek uščulo, jer ako se usmrdi u pravom smislu, kada se više ne smije konzumirati, ono podliježe pod pravilo o šteti (ka'idetu-d-darer) zbog čega se nalaže zabrana njegova konzumiranja.

${ }^{14}$ Ibn Abidin, Hašijetu Ibn-Abidin, 5/195.

${ }^{15}$ Kasani, El-Bedai', 5/35-36; Ibn Abidin, Hašijetu Ibn Abidin, 5/195.
} 
Po drugom stavu meso takve ribe se smije jesti, jer se ti razlozi načelno mogu uvažiti uzrocima pomora ribe, što znači da je takva riba uginula zbog poznatog razloga i ne smatra se plutajućom. Drugo mišljenje je prihvatljivije i po njemu se izdaju fetve u mezhebu. Treba još istaći da ulovljenu ribu nije dozvoljeno jesti sve dok sama ne ugine ili dok se ne usmrti na neki drugi način. ${ }^{16}$

\section{Stav ostalih islamskih pravnika o pitanju vodenih životinja}

Ostali islamski pravnici smatraju da je meso svih vrsta vodenih životinja dozvoljeno konzumirati, čak i bez klanja. Oni čak smatraju da je dozvoljeno jesti i meso ribe koja ugine prirodnom smrću, tj. meso plutajuće ribe. ${ }^{17} \mathrm{Na}$ osnovu ovog mišljenja muslimanu je dozvoljeno konzumirati i meso vodozemaca: krokodila, morskih kornjača, žaba i rakova.

Treba istaći da se vodene ptice ne ubrajaju u morske ili vodene životinje jer ne žive u vodi. One samo po potrebi, tj. radi pribavljanja hrane, zarone u vodu pa ponovo izlaze i lete na kopno. Zbog toga bez klanja njihovo meso nije dozvoljeno konzumirati.

Protagonisti ovog mišljenja međusobno se razlikuju oko detalja dozvole konzumiranja mesa određenih morskih životinja pa ćemo se na to ukratko osvrnuti u nastavku rada.

\section{Stav malikijskih pravnika}

O konzumiranju mesa morskog psa i svinje malikijski pravnici imaju dva mišljenja. Po jednima je to dozvoljeno, po drugim pokuđeno. Preferira se prvo mišljenje. Konzumiranje mesa morske svinje malikijski pravnici smatraju pokuđenim (mekruh tenzih). Oni također smatraju da je dozvoljeno peći i kuhati ribu prije nego što se očisti pa makar bila i živa tvrdeći da se to ne smatra mučenjem, jer

\footnotetext{
16 Ibid.

17 Ševkani, Nejlu-l-evtar, 8/147. Kada je u pitanju plutajuća riba, tj. ona koja ugine prirodnom smrću, po mišljenju većine islamskih pravnika dozvoljeno ju je jesti što je sukladno pravilu da su u načelu sve stvari dozvoljene. Međutim, ukoliko je takva riba već pokvarena ili se ustanovi da je njeno konzumiranje opasno po ljudsko zdravlje, bez obzira iz kojih razloga, takvu ribu je onda zabranjeno konzumirati po saglasnosti svih islamskih pravnika.
} 
vodene životinja, kada se izvade iz vode, imaju status zaklanih životinja. ${ }^{18}$

\section{Stav šafijskih pravnika}

Šafijski pravnici preporučuju da se vodene životinje, koje odmah nakon vađenja iz vode ne umiru, poput velikih riba, trebaju zaklati. Klanje, kad su ribe u pitanju, treba biti od repa, a kod morskih životinja koje liče kopnenim - od vrata.

Po šafijskim pravnicima vodene životinje koje brzo umiru nakon vađenja iz vode pokuđeno je klati i sjeći dok su još žive. Međutim, po oficijelnom mišljenju šafijskog mezheba sve vodene i morske životinje dozvoljeno je konzumirati.

Ali pored oficijelnog mišljenja postoje i druga mišljenja kod šafijskih pravnika. Neka od njih su identična mišljenju hanefijskih pravnika. Po nekima se pak pravi komparacija vodenih i kopnenih životinja. One vodene životinje koje su po obliku slične kopnenim koje se jedu, dozvoljeno je jesti, dok one koje su sliče onima koje nije dozvoljeno, nije. ${ }^{19}$

\section{Stav hanbelijskih pravnika}

Hanbelijski pravnici smatraju da je meso vodozemaca, poput vodenog psa, kornjače i raka dozvoljeno konzumirati pod uvjetom da se prije toga zakolju. Iz opće dozvole izuzimaju samo tri vrste vodenih životinja: žabe, zmije i krokodile jer smatraju da je njihovo meso zabranjeno konzumirati: žablje - zbog toga što ih je zabranjeno ubijati, zmijsko - zbog ogavnosti, a krokodilsko - zbog toga što krokodili imaju očnjake kojima trgaju plijen.

Primjećuje se da iz opće dozvole nisu izuzeli morskog psa i pored toga što i on ima očnjake. Konzumiranje njegovog mesa nisu zabranili zbog toga što se morski pas smatra jednom vrstom ribe koja živi samo u moru, za razliku od krokodila. ${ }^{20}$

Hanbelijski pravnici, kao i hanefijski, zabranjuju konzumirati ribu prije nego što se usmrti ili ne ugine. Također smatraju pokuđenim

\footnotetext{
${ }^{18}$ Derdir, Eš-Šerhu-s-sagir, 1/312, 322-323; Hirši, Hašijetu-l-Hirši, 1/83.

${ }^{19}$ Remli, Nihajetu-l-muhtadž, 8/143; Hejtemi, Tuhfetu-l-muhtadž, 8/112-114.

${ }^{20}$ Ibn Kudame, El-Mukni', 3/529, Rehibani, Metalibu uli-n-nuha, 6/315, 329.
} 
i peći je prije nego što umre jer je to bespotrebno mučenje: riba nakon što se izvadi iz vode, brzo umire i nema nikakve poteškoće da se njena smrt i sačeka. ${ }^{21}$

Dokazi pravnika koji dozvoljavaju konzumiranje svih morskih životinja

Protagonisti mišljenja po kojem je dozvoljeno jesti meso svih vodenih životinja svoj stav temelje na sljedećim dokazima:

- Uzvišeni je rekao: «Ni dva mora nisu jednaka: jedno je slatko i prijatno - voda mu se lahko pije, a drugo je slano i gorko; vi iz svakog jedete svježe meso i vadite nakit kojim se kitite.»» ${ }^{22}$

«Vama se dopušta da u moru lovite i da ulov jedete, da se njime vi i putnici koristite. ${ }^{23}$

Dakle, u citiranim ajetima Uzvišeni nije napravio razliku između životinja koje ljudi nazivaju ribom i onih koje nazivaju drugim imenima poput morske svinje, medvjeda itd., što znači da se ne mogu podvesti pod status kopnenih životinja.

- Poslanik, a.s., kada je bio upitan o abdestu morskom vodom, rekao je sljedeće: «Njegova voda je čista a krepalina dozvoljena.» ${ }^{24}$ Ovaj hadis eksplicite potvrđuje da je sve što živi u moru dozvoljeno bez obzira da li se ulovilo živo ili našlo uginulo.

- Svoj stav dokazuju također i hadisom koji prenosi Ebu Zubejr Mekki a bilježi Muslim. U njemu on između ostalog veli: «Allahov Poslanik, a. s., poslao nas je da presretnemo kurejševičku karavanu, a za vođu nam je odredio Ebu Ubejdu. Pri polasku nam je dao samo posudu hurmi jer nije imao ništa drugo. Ebu Ubejd nam je za hranu davao samo po jednu hurmu /.../. Uputili smo se prema moru. Kada smo mu se približavali, na njegovoj obali smo ugledali nešto uzdignuto poput brežuljka. Kada smo se približili, vidjeli smo ogromnu ribu zvana 'anber /.../. Jeli smo njeno meso mjesec dana a bilo nas je tri stotine. Ugojili smo se svi. A čak smo se od njena mesa

21 Kasani, El-Bedai', 5/35-36, Ibn Abidin, Hašijetu Ibn Abidin, 5/195, Dusuki Hašijetu-d-Dusuki, 3/115, Hirši, Hašijetu-l-Hirši, 1/93, Remli, Nihajetu-l-muhtadž, 8/143, Hetemi, Tuhfetu-l-muhtadž, 8/174-175, Rehibani, Matalibu uli-n-nuha, $6 / 328$.

${ }^{22}$ Kur'an, Fatir, 12.

${ }^{23}$ Kur'an, El-Maide, 26.

${ }^{24}$ Bilježi ga Malik. Pogledaj: Ibn Hadžer, Telhisu-l-habir, 1/9. 
opskrbili i za puta. Kada smo došli u Medinu, ispričali smo to Allahovom Poslaniku, a.s., pa je rekao: 'To je bila nafaku koju vam je Allah dodijelio. Imate li sa sobom išta od njena mesa, da i ja probam?' Pa smo mu dali.» ${ }^{25}$

Citirani hadis aludira na tri propisa:

1. da je, pored riba, u normalnom stanju i u nuždi dozvoljeno jesti i meso ostalih vrsta morskih životinja;

2. da morske životinje nije potrebno klati;

3. da je dozvoljeno jesti plutajuće morske životinje za koje se ne zna da li su umrle prirodnom smrću ili zbog nekog drugog razloga;

4. da ribolov politeiste nema uticaja na dozvoljenost konzumiranja mesa ulovljene životinje, jer ako je strvina morskih životinja dozvoljena, onda njihov ulov od strane bilo koga nema uticaja na dozvoljenost ili zabranjenost konzumiranja mesa ulovljene životinje.

Utroba male i sitne ribe po saglasnosti pravnika četiriju mezheba smatra se čistom zbog teškoće da se očisti. Utroba velikih riba po hanefijskim, hanbelijskim i nekim malikijskim pravnicima, Derdiru i Ibn Arabiju, smatra se čistom za razliku od šafijskih i većine malikijskih pravnika.

Prema tome, ako se njihova utroba smatra čistom, onda će dozvola konzumiranja zavisiti od mišljenja medicinskih stručnjaka: ako ustanove da je štetna po ljudsko zdravlje, biće zabranjena, dok u protivnom neće. $^{26}$

\section{Kopnene životinje}

Pod kopnenim životinjama se misli na životinje i ptice koje žive na kopnu. Dijele se sukladno svojim vrstama i osobinama. S obzirom na sličnost šerijatskih propisa koji se odnose na njih, mogu se podijeliti na sljedeće vrste.

\footnotetext{
${ }^{25}$ Bilježi ga Muslim, 3/1536.

${ }^{26}$ Ibn Abidin, Hašijetu Ibn Abidin, 1/212; Derdir, Eš-Šerhu-S-sagir, 1/22; Rehibani, Metalibu uli-n.-nuha, 1/234.
} 
Deve, sve vrste krava i sitna stoka, ovce i koze spadaju u stoku. Njihovo meso je dozvoljeno konzumirati po konsenzusu islamskih pravnika utemeljenom na mnogim pravnim tekstovima, od kojih su i ovi: «I stoku On za vas stvara; njome se od hladnoće štitite, a i drugih koristi imate, njome se i hranite.»" ${ }^{27}$; Allah je za vas stvorio životinje, da na nekima jašete, a da neke jedete.» ${ }^{28}$ Riječ «el-en'am» upotrijebljena $\mathrm{u}$ spomenutim ajetima po konsenzusu lingvista arapskog jezika odnosi se na spomenute životinje. ${ }^{29}$

\section{Druga vrsta: Zečevi}

Po većini islamskih pravnika zečije meso je dozvoljeno konzumirati. Od Enesa, r.a., prenosi se da je rekao: «Jednom smo poplašili zeca pa su ga neku potjerali i uhvatili. Uzeo sam ga i donio Ebu Talhi. Zaklao ga je i poslao Poslaniku, a.s., batak kojeg je i uzeo.» ${ }^{30}$ Muhammed b. Safvan je rekao: «Ulovio sam dva zeca i zaklao ih bijelim oštrim kamenom. O tome sam obavijestio Allahova Poslanika, s.a.v.s., pa mi je rekao da ih pojedem.» ${ }^{31}$

Zečevi nisu ogavne životinje, nemaju očnjake niti postoji pravni tekst koji zabranjuje konzumiranje njihova mesa. Nepostojanje tih elemenata obavezuje da to konzumiranje bude dozvoljeno.

Navodi se da je zečije meso jeo i Ebu Vekkas, a smatrali su ga dozvoljenim Ebu Seid el-Hudri, Ata, Ibn Musejjib, Lejs, Ebu Sevr i Ibn Munzir. ${ }^{32}$

\footnotetext{
${ }^{27}$ Kur'an, En-Nahl, 5.

${ }^{28}$ Kur'an, Gafir, 79.

${ }^{29}$ Kasani, El-Bedai', 5/35-36; Dusuki, Hašijetu-Dusuki 'ala-š-šerhi-l-kebir, 2/115; Remli, Nihajetu-l-muhtadž, 8/142; Rehibani, Metalibu uli-n-nuha, 6/328.

${ }^{30}$ Bilježi ga Buharija, Fethu-l-Bari, 9/661 i Muslim, 3/1547.

31 Bilježi ga Ebu Davud, 3/249, Ibn Madže, 2/108, a Buharije smatra da je vjerodostojan. Zejle'i, Nasbu-r-rajeti, 4/201.

32 Kasani, El-Bedai', 5/39; Derdir, Eš-Šerhu-s-sagir, 1/322; Remli, Nihajetu-lmuhtadž, 8/143; Ibn Kudame, El-Mugni, 11/81-82; Ibn Hazm, El-Muhalla, 7/432.
} 
U zvijeri se ubrajaju sve životinje koje imaju očnjake bile one domaće poput psa i mačke ili divlje poput lava, vuka, leoparda, lisice, divlje mačke, majmuna, medvjeda, slona itd.

\section{Pravni status konzumiranje mesa zvijeri}

Po hanefijskim, šafijskim i hanbelijskim pravnicima, i jednom mišljenju kod malikijskih pravnika, nije dozvoljeno konzumirati meso zvijeri. Ebu Jusuf i Muhammed smatraju da je meso lisice i hijeno dozvoljeno konzumirati. ${ }^{33}$

Većina islamskih pravnika svoje mišljenje temelje na hadisu $\mathrm{u}$ kojem je Poslanik, a.s., rekao: «Svaka zvijer koja ima očnjake je

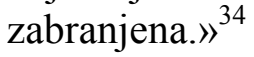

A pravnici koji smatraju da je hijenino meso halal, svoj stav potkrepljuju mnogobrojnim hadisima. Tako se od Ibn Ebi Ammara prenosi da je rekao: «Pitao sam Džabira b. Abdullaha o jedenju hijenina mesa pa je rekao da je dozvoljeno. Potom sam ga upitao da li ju je dozvoljeno loviti. Rekao je da jest. Pa sam ga upitao da li je to čuo od Allahova Poslanika, a.s., što je i potvrdio." ${ }^{\text {"35 }}$ Također se od Nafi'a, Ibn Omerova sluge, bilježi da je rekao: »Neki čovjek je rekao Ibn Omeru da S'ad b. Ebi Vekkas jede hijenino meso pa to on nije osudio.»

Po oficijelnom mišljenju malikijskog mezheba pokuđeno je (mekruh tenzih) jesti meso domaćih zvijeri poput mačke, psa itd., i divljih poput vuka, lisice, medvjeda itd. Konzumiranja majmunskog mesa dozvoljeno je, ali to nije i oficijelno mišljenje tog mezheba. ${ }^{36}$

Treba još istaći da šafijski pravnici dozvoljavaju konzumiranje mesa nekih od spomenutih zvijeri kao i meso hijene, lisice, vjeverice, sokola i kune obrazlažući to da su im očnjaci mali i zakržljali. ${ }^{37}$

\footnotetext{
${ }^{33}$ Kasani, El-Bedai', 5/39; Ibn Abidin, Hašijetu Ibn Abidin, 5/194.

${ }^{34}$ Bilježi ga Malik, El-Muvetta, 2/496; Muslim, 3/1534.

${ }^{35}$ Bilježi ga Tirmizi, 4/252. Buharija smatra da je ovaj hadis vjerodostojan, Ibn Hadžer, Telhisu-l-habir, 4/152.

${ }^{36}$ Derdir, Šerhu-l-kebir m'ea Hašijeti-d-Dusuki, 2/104.

${ }^{37}$ Remli, Nihajetu-l-muhtadž, 8/143-144.
} 
Hanbelijski pravnici od spomenutih vrsta zvijeri dozvoljavaju samo konzumiranje mesa hijenina, a za lisicu i divlju mačku vele da postoji predaja koja dozvoljava konzumiranje njihova mesa. ${ }^{38}$

Malikijski pravnici svoj stav dokazuju sljedećim ajetom: «Reci: 'Ja ne vidim u onome što mi se objavljuje da je ikome zabranjeno jesti ma šta drugo osim strvi, ili krvi koja ističe, ili svinjskog mesa - to je doista pogano - ili što je kao grijeh zaklano u nečije drugo, a ne u Allahovo ime.'» ${ }^{39}$ Dakle, meso zvijeri nije spomenuto u ajetu, što znači da nije zabranjeno. A što se tiče hadisa $u$ kojima se zabranjuje konzumiranje mesa životinja koje imaju očnjake, malikijski pravnici smatraju da te zabrane aludiraju na pokuđenost (kerahe), a ne na zabranjenost (tahrim) ${ }^{40}$

Četvrta vrsta: Divlje životinje koje nemaju očnjake $i$ ne spadaju $u$ glodare, gmizavce $i$ insekte

U ovu vrstu se ubrajaju gazele, zebre, divlje koze, divlje krave, divlje deve itd. Meso ove vrste divljih životinja po konsenzusu islamskih pravnika dozvoljeno je jer se ne smatra ogavnim. Međutim, malikijski pravnici vele da ukoliko se divlji magarac pripitomi, dobiva status domaćeg magarca, o čemu će biti riječi kasnije. U slučaju da ponovo podivlja, vraća se na prvobitni status, tj. status divlje životinje. ${ }^{41}$

Peta vrsta: Ptice koje imaju kandže kojima love (ptice grabljivice)

U ovu vrstu ubrajaju se sve ptice grabljivice poput orla, sokola, jastreba, sove itd. Konzumiranje njihova mesa po hanefijskom mezhebu je pokuđeno (mekruh tahrim), a kod ostalih pravnika, osim malikijskih, zabranjeno je (haram). ${ }^{42}$

Malikijski pravnici, po oficijelnom mišljenju mezheba, smatraju da je konzumiranje mesa ptica grabljivica dozvoljeno pa makar se hranile i nečistoćom. Prenosi se od nekih njihovih pravnika

\footnotetext{
${ }^{38}$ Ibn Kudame, El-Mukni', 3/525-527.

${ }^{39}$ Kur'an, El-En'am, 145.

${ }^{40}$ El-Badži, El-Munteka, 3/525-528.

${ }^{41}$ Derdir, Šerhu-l-kebir m'ea Hašijeti-d-Dusuki, 2/104.

${ }^{42}$ Kasani, El-Bedai', 5/39; Remli, Nihajetu-l-muhtadž, 8/14; Ibn Kudame, El-Mukni, 3/527; Ibn Hazm, El-Muhalla, 7/403.
} 
da zabrana konzumiranja mesa ptica grabljivica ima status pokuđenosti (tahrim). ${ }^{43}$

Pravnici koji zabranjuju konzumiranje mesa ptica grabljivica svoj stav temelje na hadisu koji prenosi Ibn Abbas, r.a. U hadisu stoji da je Allahov Poslanik, s.a.v.s., zabranio jedenje mesa životinja koje imaju očnjake i ptica koje imaju kandže. ${ }^{44}$

Peradi i ptica koje nemaju kandže za lov plijena, poput pijetlova, vrabaca, golubova itd., ne potpadaju pod ovu kategoriju i konzumiranje njihova mesa je dozvoljeno. ${ }^{45}$

Malikijski pravnici svoj stav opravdavaju citiranim ajetom $u$ kojem stoji: «Reci: 'Ja ne vidim u onome što mi se objavljuje da je ikome zabranjeno ma šta drugo osim strvi, ili krvi koja ističe, ili svinjskog mesa - to je doista pogano - ili što je kao grijeh zaklano u nečije drugo, a ne u Allahovo ime.'’ ${ }^{46}$ Dakle, u ajetu se ne navode među zabranjenim stvarima ptice grabljivice. Iz toga se implicite zaključuje da konzumiranje njihova mesa nije zabranjeno.

\section{Šesta vrsta: Ptice koje se isključivo hrane lešinom (lešinari)}

Hanefijski, šafijski i hanbelijski pravnici su saglasni da je zabranjeno jesti meso velikog crnog i pirgavog gavrana. Hanefijski pravnici vele da je to pokuđeno (mekruh tahrim), što ima isti pravni ishod. Obje vrste ovih gavranova uglavnom se hrane samo strvinom i zbog toga je konzumiranje njihova mesa zabranjeno jer su te ptice za ljude koji imaju čistu prirodu i rezonovanje odvratne i gadljive. Isto pravilo se može primijeniti i na ostale vrste lešinara, jer se i oni većinom hrane strvinom i mesom i pored toga što ne love kandžama, nego kljunom.

Meso poljske vrste gavrana je dozvoljeno zbog toga što se većinom hrani plodovima i žitaricama. I ovo mišljenje zastupaju i šafijski i hanbelijski pravnici. ${ }^{47}$

Što se tiče malih gavranova i ostalih sličnih ptica koje se hrane i žitaricama i strvinom, po većini islamskih pravnika, konzumiranje

\footnotetext{
${ }^{43}$ Rehuni, Metalibu uli-n-nuha, 3/39.

${ }^{44}$ Bilježi ga Muslim, 3/1534.

${ }^{45}$ Ibn Hazm, El-Muhalla, 4/405.

${ }^{46}$ Kur'an, El-En'am, 145.

${ }^{47}$ Remli, Nihajetu-l-muhtadž, 8/143; Ibn-Kudame, El-Mukni', 3/527.
} 
njihova mesa je zabranjeno. Ebu Hanife smatra da je dozvoljeno, a Ebu Jusuf da je pokuđeno.

Dakle, hanefijski pravnici pri definiranju halal i haram mesa ove vrste ptica ne uzimaju u obzir njihova imena, osobine, veličinu i boju, nego samo hranu kojom se hrane. Prema tome, meso ptica koje se pretežno hrane strvinom je mekruh tahrim jesti. One koje se hrane i strvinom i žitaricama po Ebu Hanifi su dozvoljene, što je suprotno Ebu Jusufovu stavu. Meso ptica koje se isključivo hrane samo biljnom hranom dozvoljeno je konzumirati po saglasnosti islamskih pravnika. $^{48}$

Malikijski pravnici načelno dozvoljavaju meso svih vrsta gavranova. A prenosi se i mišljenje nekih njihovih pravnika da nije dozvoljeno konzumirati meso gavrana lešinara. ${ }^{49}$

Oni pravnici koji smatraju da je zabranjeno ili mekruh tahrim jesti gavranovo meso, svoj stav dokazuju hadisom koji prenose Aiša i Ibn Omer, r.a. Po tom je hadisu Poslanik, a.s., rekao: «Pet opasnih vrsta životinja se ubijaju i u haremu i izvan harema: zmija, crno-bijeli gavran, miš, pas koji ujeda i jedna vrsta sokola ( hudja).» ${ }^{50}$

Dakle, crno-bijelog gavrana koji je spomenut u citiranom hadisu dozvoljeno je ubijati kao i ostale vrste gavranova $i$ to na osnovu opće forme koja je upotrijebljena u drugim verzijama ovog hadisa.

Malikijski pravnici pak smatraju da dozvola ubijanja neke životinje ne aludira i na zabranu konzumiranja njena mesa. Ova konstatacija se može potvrditi i sljedećim ajetom: «Reci: 'Ja ne vidim u onome što mi se objavljuje da je ikome zabranjeno jesti ma šta drugo osim strvi, ili krvi koja ističe, ili svinjskog mesa - to je doista pogano - ili što je kao grijeh zaklano u nečije drugo, a ne u Allahovo ime'». ${ }^{51}$ Prema tome, gavran se ne spominje u citiranom ajetu, što znači da je njegovo meso dozvoljeno konzumirati.

Oni koji dozvoljavaju jedenje nekih vrsta gavranova a zabranjuje druge svoj stav dokazuju činjenicom da se u citiranim hadisima navodi i spominje samo crno-bijeli gavran. Općepoznato je

\footnotetext{
${ }^{48}$ Kasani, El-Bedai', 5/40; Ibn Abidin, Hašijetu Ibn Abidin, 5/194.

49 Derdir, Ě̌-Šerhu-l-kebir, 2/119; Remli, Nihajetu-l-muhtadž, 8/143; Ibn Kudame, El-Mukni', 3/527.

${ }^{50}$ Bilježi ga Buharija, Fethul-l-Bari, 4/34; Muslim, 2/857-858.

${ }^{51}$ Kur'an, El-En'am, 145.
} 
da se ta vrsta gavrana većinom hrani lešinom i da je, kao takva, kao i one koje joj sliče, zbog toga i zabranjena. Dakle, meso ostalih vrsta koje se većinom hrane biljnom hranom dozvoljeno je.

Sedma vrsta: Ptice koje ne love kandžama niti se isključivo hrane strvinom

Pod ovom vrstom se misli na sve vrste domaćih pernatih životinja, golubova, vrabaca i ostalih ptica na koje se odnose spomenute osobine. Njihovo je meso po hanefijskim pravnicima dozvoljeno konzumirati.

Malikijski pravnici po oficijelnom mišljenju mezheba također smatraju da je dozvoljeno konzumirati meso svih spomenutih vrsta ptica pa makar se hranile i nečistim stvarima (džellala). Iz te opće dozvole izuzimaju slijepog miša i vele da je mekruh konzumirati njegovo meso, kao i meso pupavca i sureda (vrste ptice).

Svoj stav temelje na hadisu u kojem stoji da je Poslanik, a.s., zabranio ubijanje četiriju vrsta životinja: mrava, pčela, pupavca i sureda. ${ }^{53}$ Dakle, oni su zabranu u citiranom hadisu razumjeli u smislu pokuđenosti (el-kerahe), a ne u smislu zabrane (et-tahrim). Prenosi se da i konzumiranje mesa zidarskih lasta ${ }^{54}$ smatraju pokuđenim iz poštovanje prema onima na čijim kućama one prave svoja gnijezda. ${ }^{55}$

Šafijski i hanbelijski pravnici smatraju da je zabranjeno jesti meso svih životinje koje je Zakonodavac naredio da se ubijaju, kao i meso onih životinja koje je zabranio da se ubijaju, a i onih koje su ogavne. Meso ostalih životinja na koje se ne odnose spomenute naznake je dozvoljeno.

Međutim, treba istaći da se ove dvije pravne škole pri primjeni ovog mišljenje neznatno razlikuju oko pitanja dozvole konzumiranja mesa određenih vrsta ptica. Npr. po šafijskim pravnicima zabranjeno je konzumirati meso papagaja i pauna zbog ogavnosti hrane kojom se hrane, dok je po mišljenju hanbelijskih pravnika to dozvoljeno.

\footnotetext{
52 Ibn Abidin, Hašijetu Ibn Abidin, 5/194.

${ }^{53}$ Bilježi ga Ebu Davud, 5/418-419. Vidi: Ibn Hadžer, Telhisu-l-habir, 2/270.

${ }^{54}$ To su laste koje prave gnijezda na zidovima kuća.

${ }^{55}$ El-Mevsu'atu-l-fikhijjetu, 5/137.
} 
Po mišljenju većine islamskih pravnika, tj. šafijskih, hanbelijskih i mišljenju nekih malikijskih pravnika, dozvoljeno je konzumirati meso svih vrsta konja. ${ }^{56}$ Svoj stav temelje na sljedećim hadisima:

Od Džabir b. Abdullah, r.a., prenosi se da je Poslanik, a.s., na dan Bitke na Hajberu zabranio meso pitomih magaraca a dozvolio konjsko meso. ${ }^{57}$ Također se prenosi od Esme, Ebi Bekrove kćeri, da je rekla: «Za vrijeme Poslanika, a.s., klali smo konje i jeli njihovo meso a bili smo u Medini..» ${ }^{58}$

Po hanefijskim pravnicima i mišljenju nekih malikijskih pravnika konzumiranje konjskog mesa se smatra pokuđenim (mekruh tenzih). Svoj stav temelje na činjenici da se o tome prenose različite predaje i što oko dozvoljenosti konzumiranja ovakvog mesa prethodnici nisu bili saglasni. Zbog toga su, iz opreznosti, donijeli takav stav o konzumiranju ovog mesa, kao i zbog toga što se zbog klanja konja umanjuju odbrambena moć države. ${ }^{59}$

Pošto je po hanefijskim pravnicima konzumiranje konjskog mesa pokuđeno, na osnovu toga su oni zaključili da je voda koju je konj pio (s'ur) čista, kao i konjsko mlijeko. Takav zaključak donijeli su zbog toga što je ta pokuđenost proistekla iz poštovanja i uvažavanja konja, a ne zbog nečistoće konja. Konji su u prošlosti bili osnovno sredstvo u ratu i odbrani države. Njihovim posjedovanjem i uzgojem zastrašivao bi se neprijatelj. Tu činjenicu konstatuje i Kur'an: «I protiv njih pripremite koliko god možete snage i konja za boj, da biste time zaplašili Allahove i vaše neprijatelje.. ${ }^{60}$

U drugoj predaji koja se prenosi od Ebu-Hanife putem Hasana b. Zijada navodi se da je konzumiranja konjskog mesa mekruh tahrim. Čak i neki malikijski pravnici smatraju da je konzumiranje konjskog mesa haram. ${ }^{61}$

\footnotetext{
56 Remli, Nihajetu-1-muhtadž, 8/143; Ibn Kudame, El-Mugni, 11/66; Derdir, EšŠerhu-l-kebir, 2/117.

${ }^{57}$ Bilježi ga Buharija, Fethu-l-Bari, 9/649 i Muslim, 3/1541.

${ }^{58}$ Bilježi ga Buharija, Fethu-l-Bari, 9/648 i Muslim, 3/1541.

${ }^{59}$ Kasani, El-Bedai', 5/38-39; Ibn Abidin, Hašijetu Ibn Abidin, 1/148, 5/193; Derdir, Eš-Šerhu-l-kebir, 2/117.

${ }^{60}$ Kur'an, El-Enfal, 60.

${ }^{61}$ Ibn Abidin, Hašijetu Ibn Abidin, 5/193; Derdir, Eš-Šerhu-1-kebir, 2/117.
} 
Svoj stav temelje na riječima Uzvišenog: «I konje, i mazge, i magarce - da ih jašete, i kao ukras». ${ }^{62}$ Ograničenje koristi od spomenutih životinja samo na jahanje i ukras aludira da one nisu za ishranu.

Također se prenosi od Halida b. Velida, r.a., da je Poslanik, a.s., zabranio meso konja, mazgi, magarca, divljači koja ima očnjake i ptica koje imaju kandže.»» ${ }^{63}$ Ali pošto ni ajet a niti hadis na zabranu ne ukazuju kategorično, ne može se onda tvrditi da je konzumiranje konjskog mesa zabranjeno (haram), nego samo pokuđeno (mekruh tahrim), kako tvrde hanefijski pravnici.

\section{Deveta vrsta: Domaći magarci}

Većina islamskih pravnika smatra da je konzumiranje mesa domaćih magaraca zabranjeno dok hanefijski pravnici smatraju da je to mekruh tahrim. Takav status se ne mijenja bez obzira da li je magarac ostao pitom ili je podivljao.

Svoj stav temelje na sljedećim dokazima: Enes b. Malik prenosi da je Allahov Poslanik, a.s., u jednom pohodu naredio glasniku da oglasi sljedeće: «Allah i Njegov Poslanik vam zabranjuju meso pitomih magaraca jer je nečisto.» Tako su se kotlovi prosuli, a bili su puni magarećeg mesa. ${ }^{64}$

Od Džabira b. Abdullaha, r.a., prenosi se da je Allahov Poslanik, a.s., na dan Bitke na Hajberu zabranio meso pitomih magaraca, a dozvolio konjsko.» ${ }^{65}$ Ibn-Hazm tu Poslanikovu zabranu prenosi putem devet ashaba lancima jasnim kao sunce, kako to navodi. I veli da je prenesena tevatur predajom nakon čega nikome nije dozvoljeno postupiti suprotno. ${ }^{6}$

Iz tematike koja tretira ovo pitanje može se reći da u vezi s konzumiranjem mesa pitomih magaraca islamski pravnici zastupaju tri stava: da je to haram ili mekruh tahrim, da je mekruh tenzih (to je stav

\footnotetext{
${ }^{62}$ Kur'an, En-Nahl, 8.

${ }^{63}$ Ibn Hazm, El-Muhalla, 7/408; Ibn Hadžer, Telhisu-l-habir, 41.

${ }^{64}$ Ibn Hadžer, Fethu-l-Bari, 9/653.

${ }^{65}$ Naprijed mu je navedena verifikacija.

${ }^{66}$ Ibn Hazm, El-Muhalla, 7/406-407.
} 
malikijskih pravnika) i da je to dozvoljeno (što je mišljenje Ibn Abbasa, Aiše, Ikrime, Ebu Vaila i Bišra). ${ }^{67}$

\section{Deseta vrsta: Svinje}

Svi dijelovi svinje - meso, mast, koža, dlaka - po mišljenju većine islamskih pravnika su zabranjeni (haram) na osnovu riječi Uzvišenog: «Reci: 'Je ne vidim u ovome što mi se objavljuje da je ikome zabranjeno jesti ma šta drugo osim strvi, ili krvi koja ističe, ili svinjskog mesa, - to je doista pogano -, ili što je kao grijeh zaklano u nečije drugo, a ne u Allahovo ime. ${ }^{1668}$ Elusi kod tumačenja ovog ajeta veli: «Meso je posebno istaknuto i pored toga što su i ostali njeni dijelovi zabranjeni, za razliku od pravnika bukvalista (zahirija).» ${ }^{69}$ Međutim, pripisivanje ovakvog mišljenja zahirijama je diskutabilno zbog toga što Ibn Hazm u svom djelu El-Muhalla prenosi konsenzus islamskih pravnika da su svi dijelovi svinje zabranjeni (haram) ${ }^{70}$

Jedanaesta vrsta: Glodari, gmizavci i insekti

Arapska riječ el-hašerat aludira na glodare, gmizavce, guštere i insekte. Dakle, ova vrsta životinja se može podijeliti na dvije vrste: životinje koji imaju krvotok poput zmija, miševa, guštera itd., i insekte koji nemaju krvotok poput pauka, mrava, skakavaca, muha itd.

Ovakva podjela ove vrste životinja ne utječe na pravni status konzumiranja njihova mesa, ali ima utjecaja na jedno drugo pitanje. To je pitanje njihove šerijatske čistoće i nečistoće. Na osnovu te podjele, strvina životinja koje imaju krvotok je nečista i onečišćuje male količine tečnih tvari, za razliku od onih koji nemaju krvotoka. S obzirom na to da sve nemaju isti propis u vezi s konzumiranjem njihova mesa, na sljedećim stranicama ćemo se ukratko osvrnuti na svaku od njih.

\footnotetext{
${ }^{67}$ Kasani, El-Bedai', 5/37; Dusuki, Hašijetu-d-Dusuki, 2/117; Remli, Nihajetu-lmuhtadž, 8/144; Ibn Kudame, El-Mukni', 3/525; Ibn Kudame, El-Mugni, 11/65-66; Ibn Hazm, El-Muhalla, 7/406-407.

${ }^{68}$ Kur'an, El-En'am, 145.

${ }^{69}$ Elusi, Ruhu-l-me'ani, 2/42.

${ }^{70}$ Ibn Hazm, El-Muhalla, 7/390.
} 


\section{Skakavci}

Islamski pravnici su saglasni da je konzumiranje skakavaca dozvoljeno. Svoj stav temelje na hadisu u kojem se kaže: «Dozvoljene su nam dvije vrste strvina i dvije vrste krvi. Od strvina su dozvoljeni skakavci i ribe, a od krvi slezena i jetra.» ${ }^{71}$

Većina islamskih pravnika također smatra da nema potrebe da se skakavci kolju prije jela, dok malikijski smatraju da je to neophodno radi ubrzanja njihova smrt $i$ da pri tome treba proučiti Bismillu. Šafijski pravnici smatraju pokuđenim klanje skakavaca i njihovo komadanje prije nego što uginu. Šafijski pravnici su također decidni u uvjerenju da ih je dozvoljeno pržiti bez čišćenja i da mast na kojoj se prže zbog toga ne postaje nečistom. Ali u isto vrijeme strogo zabranjuju da se prže živi jer se na taj način muče. ${ }^{72}$

A hanbelijski pravnici smatraju da je to dozvoljeno $i$ da je to mučenje zbog potrebe, jer njihova smrt se može odužiti a njeno čekanje predstavljalo bi poteškoću. ${ }^{73}$

\section{Gušteri}

Islamski pravnici nemaju jedinstven stav o pitanju konzumiranja mesa guštera. Većina smatra da je to dozvoljeno. Svoj stav temelje na hadisu koji se prenosi od Abdullaha b. Abbasa: «Ušao sam sa Halidom b. Velidom i sa Allahovim Poslanikom, s.a.v.s., u Mejmuninu kuću pa nam je iznijela pečena guštera. Poslanik, a.s., ga nije jeo pa sam upitao: 'Allahov Poslaniče, da nije haram?!' 'Ne, ali u krajevima mog naroda ga ne jedu, pa mi se gadi.' Halid je rekao: 'Ja sam ga jeo a Allahov Poslanik, a.s., je gledao.'» ${ }^{74}$

Ebu Hanife smatra da je konzumiranje mesa guštera zabranjeno. A svoj stav temelji na hadisu koji se prenosi od Abdurrahmana $b$. Hasana a $u$ kojem veli da ih je $u$ jednoj bici zajedno sa Poslanikom, a.s., zadesila velika glad pa su ashabi našli nekog guštera, ogulila ga i stavili da se kuha. I dok su lonci ključali,

\footnotetext{
${ }^{71}$ Bilježi ga Ibn Madže, 2/1073, Darekutni, 4/272; Vidi: Ibn Hadžer, Telhisu-l-habir, 1/25-26.

${ }^{72}$ Remli, Nihajetu-l-muhtadž, 8/107; Hejtemi, Nihajetu-l-muhtadž, 8/174-175.

${ }^{73}$ Rehibani, Metalibu uli-n-nuha, 6/328.

${ }^{74}$ Bilježi ga Muslim, 3/1543.
} 
Poslanik, a.s., saznao je za to pa im je naredio da prospu lonce i bace meso. $^{75}$

Zastupnici prvog mišljenje smatraju da je hadis u kojem se zabranjuje konzumiranje mesa guštera derogiran, jer hadis je koji to dozvoljava došao poslije njega. U njemu se spominje da je tu bio prisutan Ibn Abbas, a poznato je da se on susreo sa Poslanikom, a.s., tek u Medini.

Od ashaba su Alija b. Ebi Talib i Džabir b. Abdillah smatrali pokuđenim konzumiranje gušterova mesa. Čini se da je konzumiranje mesa guštera moguće podvesti i pod mekruh tahrim a i pod mekruh tenzih. Oni koji smatraju da je mekruh tenzih, svoj stav izvode iz činjenice da su dokazi koji govore o tome oprečni. I zbog toga su mu iz opreznosti dali takav status.

Crvi

Islamski pravnici su u svojim djelima detaljno tretirali i ovo pitanje. Mi ćemo ta njihova razmatranja sažeti na način kako slijedi.

Hanefijski pravnici smatraju da su larve osa i ostalih insekata dozvoljene jesti prije nego što ožive, jer se ne smatraju strvinom. Ali nije nakon što ožive. Na osnovu tog pravila nije dozvoljeno jesti crve u siru, sirćetu, plodovima itd. ${ }^{76}$

Malikijski pravnici vele da ukoliko crv ili larva uginu u nekoj hrani i jasno se odvoje od nje, tada ih je vadžib izvaditi iz hrane zbog toga što ih je zabranjeno jesti sa tom hranom. A hrana nakon što se crvi odstrane iz nje neće se bacati jer se njihova strvina ne smatra nečistom.

A ako se jasno ne odvoje od hrane, nego se pomiješaju s njom, u tom slučaju će se hrana baciti zbog toga što je zabranjeno jesti hranu sa takvom vrstom crva i pored toga što se smatraju čistim. Hranu treba dati psima, mačkama ili nekim drugim životinjama, osim ako se ne radi o maloj količini neodvojenih crva.

Ukoliko crv ne ugine u hrani, dozvoljeno ga je jesti sa hranom ako se nađe u njoj. Treba istači da se sve navedeno odnosi na crve koji nisu nastali i razvili se u hrani bez obzira o kakvoj se hrani radilo -

\footnotetext{
75 Bilježi ga Ahmed, 4/196, Ibn-Hibban, str. 1070, a Ibn Hadžer veli da je vjerodostojan, Fethu-l-Bari, 9/666-669.

${ }^{76}$ Kasani, El-Bedai', 535-36, Ibn Abidin, Hašijetu Ibn Abidin, 5/194.
} 
voću, povrću, žitaricama itd. Ako je riječ o crvima koji su nastali i razvili se u hrani, onda ih je dozvoljeno jesti sa njom bez obzira da li se radilo o velikoj ili maloj količini crva i da li su odvojeni ili pomiješani s njom. ${ }^{77}$ Dakle, malikijski pravnici se povode za pravilom praćenja ili slijeđenja osnove.

Šafijski i hanbelijski pravnici dozvoljavaju konzumiranje svih vrsta crvi pod trima uvjetima: 1 . da se jedu sa hranom u kojoj se nađu bez obzira da li su živi ili mrtvi (odvojeno nije dozvoljeno jesti); 2. da se ne prenose odvojeno od hrane, jer ako se radi o odvojenim crvima, onda ih nije dozvoljeno konzumirati; 3 . da se ne promijeni ukus, boja i miris hrane ako je u tečnom stanju. Ako se promijeni bilo koje od tih svojstava, neće biti dozvoljeno da se konzumira ili pije zbog toga što će se smatrati zabranjenom. Pod ovo pravilo se mogu podvesti i crvi u voću i povrću nakon kuhanja. Dakle, i njih je dozvoljeno jesti ukoliko voda nije promijenila jedno od spomenutih svojstava. Ista je stvar i sa mravima koji dođu u med ili slično pa se med prokuha. ${ }^{78}$

Prenosi se od Poslanika, a.s., da mu je jedne prilike data stara hurma pa ju je počeo pregledati vadeći crve iz nje. ${ }^{79}$ Ibn Kudame veli da je bolje tako postupiti.

\section{Ostali glodari, gmizavci i insekti}

Islamski pravnici o pitanju dozvoljenosti konzumiranja ostalih glodara, gmizavaca i insekata zastupaju tri mišljenja.

Protagonisti prvog mišljenja smatraju da je zabranjeno konzumirati sve vrste insekata, gmizavaca i glodara jer se smatraju nečim što je ogavno kod ljudi zdrave prirode i poimanja. Zastupaju ga hanefijski pravnici. ${ }^{80}$

Po drugom mišljenju svi gmizavci, glodari i insekti su dozvoljeni ako njihovo konzumiranje ne šteti ljudima. Zastupaju ga malikijski pravnici, ali dozvolu uvjetuju klanjem. Ako se radi o insektima koji nemaju krvotok, treba ih klati kao što se to radi sa skakavcima, kako je to već naprijed objašnjeno. Ako se radi o

\footnotetext{
${ }^{77}$ Derdir, Eš-Šerhu-s-sagir me'a Hašijeti-s-Savi, 1/323.

${ }^{78}$ Remli, Nihajetu-l-muhtadž, 8/107.

79 Bilježe ga Ebu Davud i Ibn Madže. Munziri veli da je mursel. Vidi: 'Avnu-lm'abud, 3/436, Sunen Ibn-Madže, 2/106.

${ }^{80}$ Fetava hanije štampane na margini Fetava hindijje, 3/358.
} 
životinjama sa krvotokom, pri njihovom klanju treba se sprijeda presjeći grkljan i dvije vene, donijeti nijet i proučiti Bismilla. Za miša malikijski pravnici vele da ga je, ukoliko se utvrdi da je dospio do prljavštine, pokuđeno jesti, a ukoliko ne, onda je dozvoljeno. ${ }^{81}$

Protagonisti trećeg mišljenja prave razliku između glodara, gmizavaca i insekata koje je dozvoljeno konzumirati i onih koje nije. Šafijski pravnici npr. dozvoljavaju jesti meso glodara, kameleona, pustinjskog skočimiša, lasice, tvora i ježa. ${ }^{82}$ Hanbelijski pravnici smatraju da su jež, lasica i tvor zabranjeni. U vezi s glodarima imaju dvije predaje a preferira se ona po kojoj su dozvoljeni.

\section{Dvanaesta vrsta: Ukrštene životinje}

U ukrštene životinje se ubrajaju životinje proizvedene ukrštavanjem dviju različitih vrsta životinja. Kod ove vrste životinja mogu se pretpostaviti tri podvrste.

Prva podvrsta su one koje su proizvedene ukrštavanjem dviju različitih vrsta životinja čije je meso halal. Meso takve vrste ukrštenih životinja je po saglasnosti islamskih pravnika dozvoljeno.

Druga podvrsta su one koje su nastale ukrštavanjem dviju različitih vrste životinje čije meso je haram ili mekruh tahrim. Konzumiranje njihova mesa je zabranjeno (haram) po saglasnosti islamskih pravnika.

Treća podvrsta su životinje koje su nastale ukrštavanjem dviju različitih vrsta životinja, meso jedne od njih je haram ili mekruh tahrim a druge je halal ili mekruh tenzih. Kao primjer za ovu vrstu se može navesti mazga. O dozvoli konzumiranja njena mesa islamski pravnici nemaju jedinstven stav.

Šafijski i hanbelijski pravnici smatraju mazga i druge ukrštene životinje $u$ vezi s pitanjem dozvole njihova mesa slijede slabiju životinju, tj. nedozvoljenu vrstu. ${ }^{84}$ Šafijski pravnici smatraju da se ovo slijeđenje uvažava samo kada se zna od kojih životinja je nastala ukrštena životinja. Na osnovu toga, ako bi npr. ovca ojanjila psa a ne zna se da ju je pas oplodio, dozvoljeno bi ga bilo jesti zbog toga što

\footnotetext{
${ }^{81}$ Hirši, Hašijetu-l-Hirši, 1/81,88; Desuku, Hašijetu-d-Desuki, 2/115.

${ }^{82}$ Remli, Nihajetu-l-muhtadž, 8/144.

${ }^{83}$ Ibn Kudame, El-Mukni', 3/526, 529; Rehibani, Metalibu uli-n-nuha, 6/309, 314.

${ }^{84}$ Remli, Nihajetu-l-muhtadž, 8/144; Ibn Kudame, El-Mugni, 11/66.
} 
postoji mogućnost da se rodi mladunče potpuno različito od svoje vrste, ali je iz pobožnosti bolje da se ono ne konzumira.

Svoj stav opravdavaju činjenicom što se u ukrštenoj životinji objedinio halal i haram, pa se iz opreznosti treba preferirati haram, jer je općepoznato u islamskom pravu da se u slučaju kolizije harama i halala preferira haram. ${ }^{85}$

Hanefijski pravnici smatraju da mazga, u vezi s pitanjem dozvole njena mesa, slijedi svoju majku. Dakle, meso mazge čija je majka magarica zabranjeno je zbog njene majke, dok je meso mazge čija je majka kobila mekruh tenzih po mišljenju Ebu Hanife, a po mišljenju Ebu Jusufa i Muhammeda ozvoljeno. Npr. ako pretpostavimo da mazga može nastati ukrštavanjem konja i krave, njeno bi meso, na osnovu spomenutog pravila, bilo dozvoljeno po mišljenju svih hanefijskih ravnika. To pravilo važi za sve vrste ukrštenih životinja. ${ }^{86}$ Prema tome, kada su u pitanju ukrštene životinje, uzimaju se u obzir samo njihove majka bez obzira kakvu vrstu životinje one rodile. Npr. kada bi ovca ojanjila vuka, na osnovu tog pravila njegovo meso bi bilo halal. ${ }^{87}$

Malikijski pravnici također kod ukrštenih životinja uvažavaju pravilo slijeđenja majke - s nekim neznatnim razlikama. Oni ta pravila uslovljavaju time da ukrštena životinje ne dođe u obliku zabranjene životinje. Ako se to desilo, meso ukrštene životinje bilo bi zabranjeno i pored toga što je meso njene majke dozvoljeno. Npr. kada bi ovca ojanjila svinju, meso ukrštene životinje, u ovom slučaju svinje, bilo bi zabranjeno. Isto tako je zabranjeno jesti meso ukrštene mubah životinje ako je nastala od životinje čije je meso zabranjeno, i obratno, npr. ovcu koju rodi magarica. Ali potomstvo mladunčeta koje rodi zabranjena životinja, ukoliko se razmnoži, dozvoljeno je jesti ako je u obliku dozvoljene životinje zbog udaljenosti krvne loze.

Malikijski pravnici u vezi s pitanjem mazgina mesa navode dva mišljenja. Po prvom, koje je poznatije, zabranjeno je, a po drugom pokuđeno. Pri tome ne prave razlika na osnovu majke, oslanjaju se na posebne dokaze koji tretiraju pitanje mazgi a ne na pravilo genealogije. $^{88}$

\footnotetext{
${ }^{85}$ El-Medžlletu-l-ahkamu-l-'adlijje, čl. 46.

${ }^{86}$ Kasani, El-Bedai', 5/37.

${ }^{87}$ Ibn Abidin, Hašijetu Ibn Abidin, 1/150, 5/193, 197.

${ }^{88}$ Ibn Rušd, Bidajetu-l-mudžtehid, 1/455; Hirši, Hašijetu-1-Hirši, 1/86.
} 
Pravnici koji smatraju da mazgu, kada je u pitanju njeno meso, treba posmatrati kroz njenu majku svoje mišljenje temelje na činjenici da je ona prije rođenja bila dio svoje majke pa je i imala njen status koji je zadržala i nakon svog rođenja.

Pravnici koji smatraju da je meso mazge haram ili mekruh tahrim svoj stav temelje na dokazima iz Kur'ana i hadisa. Uzvišeni je rekao: «I konje, i mazge, i magarce - da ih jašete, i kao ukras.»" ${ }^{89}$ Uzvišeni je naveo da je spomenute životinje stvorio za jahanje i ukras, prešutio je status konzumiranja njihova mesa gdje je objašnjenje bilo potrebno, iz čega se da zaključiti da je njihovo meso zabranjeno. Od Džabira b. Abdullaha se prenosi da je rekao: "Allahov Poslanik, a.s., je na Hajberu zabranio meso pitomih magaraca i mazgi...» ${ }^{90}$ Također se prenosi od Halid b. Velida da je Allahov Poslanik, a.s., zabranio meso magaraca, konja i mazgi. ${ }^{91}$ Pravnici koji smatraju da je meso mazgi mekruh tenzih svoj stav temelje kompilacijom citiranih ajeta $i$ hadisa, kao i ajeta: «Reci: 'Je ne vidim u ovome što mi se objavljuje da je ikome zabranjeno jesti ma šta drugo osim strvi, ili krvi koja ističe, ili svinjskog mesa - to je doista pogano - ili što je kao grijeh zaklano u nečije drugo, a ne u Allahovo ime.'।» ${ }^{92}$

Iz toga se izvodi da meso mazgi nije zabranjeno. Postoji kolizija između citiranih hadisa i ajeta. Dakle, ne može se reći da je zabranjeno a niti sasvim dozvoljeno, pa je iz opreznosti najbolje reći da je mekruh tenzih.

Pravnici koji ga apsolutno dozvoljavaju svoj stav temelje na dokazima u kojima se jasno kaže da je u vezi s pitanjem hrane sve u osnovi dozvoljeno osim ono što se zabrani posebnim dokazom. Za zabranu takvog mesa ne postoje potpuno jasni i vjerodostojni dokazi, što znači da se uvažava pravilo praiskonske dozvole.

\section{Trinaesta vrsta: Životinje koje Arapi nisu poznavali u svom podneblju}

Pod ovom vrstom se misli na životinje koje nisu bile poznate kod Arapa na čijem je jeziku Kur'an i objavljen. Meso životinja koje

\footnotetext{
${ }^{89}$ Kur'an, En-Nahl, 8.

90 Bilježi ga Tirmizi i veli da je hadis hasen garib. Vidi: Mubarekfuri, Tuhfetu-lahvezi, 5/53-54.

${ }^{91}$ Tahavi, Muškilu-l-asar, 4/165.

${ }^{92}$ Kur'an, El-En'am, 145.
} 
su slične životinjama koje su oni smatrali lijepim dozvoljeno je jesti, dok je meso onih koje sliče onima koje su oni smatrali ogavnim i odvratnim zabranjeno jesti. To pravilo se zasniva na riječima Uzvišenog: «Pitaju te šta im se dozvoljava. Reci: 'Dozvoljavaju vam se lijepa jela...'» ${ }^{93}$ Dakle, dozvoljava im se ono što oni smatraju lijepim jer je Arapima upućen odgovor. Pozivaju se i na ajet: «A zabranjuju vam se odvratne stvari.» Dakle, ono što su stanovnici Hidžaza smatrali lijepim stvarima smatra se lijepim i dozvoljenim, a što su smatrali ružnim i ogavnim - zabranjeno je, jer je Kur'an objavljen na njihovom jeziku i njima se prvo obratio.

Dakle, kada se radi o ovoj vrsti životinja, tj. životinja koje ne žive u tom podneblju, treba ih usporediti sa najsličnijim koje žive. Nakon toga treba vidjeti da li su ih Arapi smatrali dobrim i lijepim. Ako jesu, onda je njihovo meso dozvoljene, i obratno. A ako ne bude postajala sličnost, smatrat će se da je njihovo meso dozvoljene zbog praiskonske dozvole, jer se u Kur'anu veli: «Reci: 'Je ne vidim u ovome što mi se objavljuje da je ikome zabranjeno jesti ma šta drugo osim strvi, ili krvi koja ističe, ili svinjskog mesa - to je doista pogano ili što je kao grijeh zaklano u nečije drugo, a ne u Allahovo ime.'> ${ }^{94}$ Ovo je mišljenje hanefijskih pravnika, ${ }^{95}$ a slično su se izjasnili i šafijski i hanbelijski pravnici ${ }^{96} \mathrm{~s}$ neznatnim razlikama.

Malikijski pravnici ne prihvataju to mjerilo za tumačenje lijepih stvari (et-tajjibat). Oni smatraju da su zabranjene samo one životinje koje su izuzete posebnim dokazima iz općih koji tretiraju tu tematiku. Dakle, sve ostale životinje koje nisu tretirane posebnim tekstovima potpadaju pod pravilo praiskonske dozvole i dozvoljeno je konzumirati njihovo meso.

\section{Životinje čije je meso privremeno zabranjeno (haram) konzumirati}

Pod ovom vrstom životinja misli se na životinje čije je meso u osnovi halal, ali se privremeno zabranjuje zbog određenih razloga, pa kada se oni uklone, dobiva prvobitni status. Ovdje se prvenstveno

\footnotetext{
${ }^{93}$ Kur'an, El-Maide, 4.

${ }^{94}$ Kur'an, El-En'am, 145.

${ }^{95}$ Ibn Abidin, Hašijetu Ibn Abidin, 5/194.

96 Šerbini, Mugni-l-muhtadžd, 4/257; Rehibani, Metalibu uli-n-nuha, 6/311.
} 
misli na životinje što su ih ulovili oni koji su u ihramima zbog hadždža ili umre.

Treba istaći da je muslimanu zabranjeno loviti divljač sve dok je u spomenutom stanju i svejedno je gdje se taj lov desio: u haremu ili izvan njega. U slučaju da muhrim ulovi neku divlju životinju, ili je uhvati i zakolje, smatrat će se strvinom i njeno meso neće biti dozvoljeno jesti ni njemu a niti bilo kom drugom. ${ }^{97}$ To se jasno vidi iz sljedećeg ajeta: «O vjernici, ne ubijajte divljač dok obavljate obrede hadždža.»» ${ }^{98}$

Pod divljači se ovdje misli na divlje životinje, srne, golubove itd. A što se tiče domaće peradi, ovaca, koza itd., dozvoljeno je muhrimu i ostalima da ih kolju i jedu. Treba još napomenuti da je muhrimu dozvoljeno loviti i jesti morske životinje. To se jasno vidi iz sljedećeg ajeta: «Vama se dopušta da u moru lovite i da ulov jedete, da se $\mathrm{s}$ njime vi i putnici koristite, a zabranjuje vam se da na kopnu lovite dok obrede hadždža obavljate.»» ${ }^{99} \mathrm{O}$ ovom pitanju su saglasni svi islamski pravnici. ${ }^{100}$

\section{Životinje čije je meso privremeno pokuđeno (mekruh) jesti}

Pod ovom vrstom se misli na životinje čije meso je u osnovi dozvoljeno jesti, ali zbog postojanja određenog razloga ono postaje privremeno pokuđeno (mekruh). Kada se ukloni takav razlog, ono postaje ponovo dozvoljeno. U ovu vrstu životinja islamski pravnici ubrajaju životinje koje se hrane nečistoćom (el-džellale). Imam Kasani je definirajući el-džellalu rekao: «Pod džellalom se misli na deve, krave i sitnu stoku koja se većinom hrani nečistoćom pa je zbog toga pokuđeno jesti njihovo meso iz razloga što se prenosi da je Poslanik, a.s., zabranio jesti meso takvih deva.» ${ }^{101}$ Od Poslanik, a.s., također se prenosi da je zabranio da se pije mlijeko od takvih životinja. ${ }^{102}$ Hadise u kojima se zabranjuje i jahanje i korištenje takvih životinja treba razumjeti u smislu da je to zbog njihova posebna mirisa $i$ da bi se na taj način izbjeglo uznemiravanje ljudi.

\footnotetext{
${ }^{97}$ Kuvajtska pravna enciklopedija, 5/147.

${ }^{98}$ Kur'an, El-Maide, 95.

${ }^{99}$ Kur'an, El-Maide, 96.

${ }^{100}$ Dusuki, Hašijetu-d-Dusuki, 2/72.

${ }^{101}$ Bilježe ga Darekutni, 4/283 i Bejheki, 9/333.

102 Ibid.
} 
Razlog zbog kojeg je njihovo meso pokuđeno konzumirati anulira se zatvaranjem takvih životinja i njihovim tovljenjem čistom hranom. O tome koliko ih dugo treba držati zatvorenim, islamski pravnici nemaju jedinstven stav. Od Muhammed se prenosi da Ebu Hanife nije određivao taj period nego je zagovarao da se životinja drži zatvorenom sve dok se ne očisti. To je i mišljenje Ebu Jusufa i Muhammeda. Prenosi se i mišljenje da se trebaju zatvoriti tri dana. Treba istači da nije pokuđeno jesti meso kokoši (el-muhalla), tj. kokoši koja nije zatvorena i koja jede i nečistoću. Ali je bolje da se zatvori sve dok se ne pročisti. Ebu Jusuf prenosi od Ebu Hanife da se takva kokoš treba zatvoriti tri dana jer je to dovoljan period da izbaci iz sebe nečistoću. ${ }^{103}$

Sličan hanefijskom stavu imaju i šafijski pravnici. Od njihovih pravnika o ovom pitanju prenose se dva stava. Protagonisti prvog smatraju da je meso takvih životinja zabranjeno, a zastupa ga Rafi'i. Sljedbenici drugog mišljenja smatraju da je pokuđeno, a zastupa ga imam Nevevi. Treba istaći da je drugo mišljenje oficijelno mišljenje mezheba, jer se zabrana u hadisu odnosi na promjenu ukusa mesa i zbog toga ne može imati status definitivne zabrane. ${ }^{104}$ Ako se prihvati da je zabranjeno ili mekruh jesti meso džellale, onda je zabranjeno ili mekruh i upotrebljavati i konzumirati njene proizvode poput jaja i mlijeka, kao što je i mekruh jahati ih bez pokrivača, jer njihov znoj ima status njihova mesa i mlijeka.

Od imama Ahmeda se prenose dvije predaje. U prvoj se veli da je zabranjeno konzumirati meso takvih životinja, i to je oficijelno mišljenje mezheba, a po drugom da je to mekruh.

Malikijski pravnici smatraju da su peradi i životinje koje se hrane nečistoćom dozvoljene, ali Ibn Rušd veli da imam Malik smatra pokuđenim jesti njihovo meso. ${ }^{106}$ Sva spomenuta mišljenja koja se odnose na džellalu temelje se na hadisima a njihove razlike su došle kao produkt njihova različita razumijevanja i shvatanja od strane islamskih pravnika.

\footnotetext{
${ }^{103}$ Kasani, El-Bedai', 5/39-40.

${ }^{104}$ Remli, Nihajetu-l-muhtadž, 8/148-147.

${ }^{105}$ Ibn Kudame, El-Mugni, 11/71-73, Ibn Hazm, El-Muhalla, 7/410.

${ }^{106}$ Ibn Rušd, Bidajetu-l-mudžtehid, 1/452.
} 


\section{Dijelovi životinja}

O pitanju dozvoljenosti konzumiranja dijelova životinja pravnici nemaju jedinstven stav. Pri donošenju konačnog pravnog statusa o njima, pravnici su u obzir uzeli vrstu ekstremiteta i stanje $u$ kojem se on odvojio od tijela. Zbog toga ćemo se ukratko osvrnuti na njihov status u konzumiranju.

Dijelovi koji se odsijeku za života životinje

Sve što se odsiječe od životinje za njena života ima status strvine i zabranjeno je konzumirati, dok ono što se odsiječe od ribe ili skakavca, dok su ovi živi, po većini pravnika je dozvoljeno, jer su njihove strvine po šerijatu dopuštene.

Dijelovi koji se odsijeku pri klanju ili poslije klanja a prije definitivne smrti

Dijelovi koji se odsijeku pri klanju imaju isti status kao i dijelovi koji se odsijeku dok je životinja živa. Po ovom pitanju islamski pravnici su saglasni. Dio koji se odsiječe poslije klanja a prije definitivne smrti po većini islamskih pravnika ima status mesa koje se odsiječe poslije definitivne smrti, tj. dozvoljeno ga je konzumirati jer ostatak života u posljednjim izdisajima, gdje smrt i život dijele momenti, ima status smrti.

Status dijelova zaklane životinje

Životinje čije je meso dozvoljeno konzumirati, poslije šerijatskog klanja definitivno postaje dozvoljeno za ljudsku ishranu. Međutim, neki dijelovi zaklane životinje tretiraju se posebno i nakon klanja i imaju poseban pravni status, npr. krv je zabranjena po konsenzusu islamskih učenjaka i prije i poslije klanja.

Hanefijski pravnici smatraju da je nakon klanja životinje čije se meso jede zabranjeno jesti njenih sedam dijelova, i to: krv koja isteče, penis, bijeli bubrezi, vagina, mjehur, žučna kesa i žlijezda

${ }^{107}$ Ibn Hazm, El-Muhalla, 7/449; Hattab, Mevahibu-l-Dželil, 3/228.

108 Ibn Hazm, El-Muhalla, 7/449; Ibn Kudame, El-Mugni, 11/53; Ibn Abidin, Hašijetu Ibn Abidin, 5/197. 
(guša). Oni svoj stav temelje na sljedećem dokazu: «Dozvoljavat će im lijepe stvari a zabranjivati ružne.» ${ }^{109}$ Spomenuti dijelovi su ogavni i odvratni ljudima zdrave prirode i osjećaja pa su zbog toga i zabranjeni. I u hadisu se navode da su ti dijelovi odvratni i ružni. Evzai prenosi od Vasila b. Ebi Džemile od Mudžahida da je rekao: «Allahov Poslanik, a.s., je zabranio od ovce/ovna: penis, bijele bubrege, vaginu, žlijezde, žučnu kesu, mjehur i krv.» ${ }^{110}$ Ibn- Abidin smatra da je od spomenutih stvari samo krv zabranjena, a da su ostale stvari mekruh tahrim. ${ }^{111}$

\section{Jaja}

Jaja koja izađu iz životinje čije se meso jede za njena života, ili nakon šerijatskog klanja, ili smrti, ali samo od životinja koje se ne trebaju klati poput riba, po konsenzusu islamskih pravnika halal su ako nisu pokvarena.

Jaja koja izađu poslije smrti životinje čije meso je halal i koja nije šerijatski zaklana a treba se zaklati poput peradi po Ebi Hanifi su dozvoljena bez obzira da li im se kora formirala ili ne. Malikijski pravnici smatraju da ih nije dozvoljeno jesti, a šafijski smatraju da se jedu samo ona čija je kora otvrdnula. Hanifijski pravnici po ovom pitanju slijede pravilo koje glasi: i jaja životinje čije meso je dozvoljeno jesti dozvoljena su, i obratno.

Malikijski pravnici smatraju da je svako jaje koje izađe iz žive ili zaklane životinje dozvoljeno jesti zbog toga što oni životinje koje nose jaja ne dijele na one čije se meso jede $\mathrm{i}$ ne jede, jer su po njihovom mišljenju sve dozvoljene.

\section{Sirišta}

Sirište koje se uzme od životinje koja je šerijatski zaklana čisto je i halal po većini islamskih pravnika. Ono koje se uzme od uginule životinje, ili one koja nije šerijatski zaklana smatra se nečistim i zabranjenim po većini islamskih pravnika. Međutim, Ebu Hanife

\footnotetext{
${ }^{109}$ Kur'an, El-'Araf, 157.

${ }^{110}$ Bilježi ga Bejheki, 10/7 i veli da je munkati', a potom ga bilježi od Ibn Abbasa i veli da je slab.

${ }^{111}$ Ibn Abidin, Hašijetu Ibn Abidin, 5/477; Kasani, El-Bedai', 5/61.
} 
smatra da su takva sirišta, analogno mlijeku, čista i halal bez obzira da li bila u tečnom ili čvrstom stanju. Ebu Jusuf i Muhammed smatraju da se trebaju, ako su u čvrstom stanju, oprati i tek nakon toga ih je dozvoljeno koristiti; ukoliko su u tečnom stanju, onda ih je zabranjeno koristi zbog toga što je sirišna kesa nakon smrti postala nečistom. ${ }^{112}$

Prema tome, sir koji se napravi sirištem od životinja zaklanih na šerijatski način čist je po saglasnosti islamskih pravnika, dok onaj koji je napravljen od sirišta uginulih životinje ili životinja koje nisu zaklane na šerijatski način ima različit status kod pravnika sukladno različitosti njihovih mišljenja o tome.

\section{Zaključak}

Studijom smo došli do sljedećih rezultata:

- Islam nije ostavio u ljudskom životu pravne praznine, već je sve segmente ljudskog života obuhvatio svojim propisima i normama, detaljno ili načelno, sukladno njihovoj važnosti i prioritetima.

- U osnovi svi izvori hrane koje je Allah na Zemlji stvorio radi čovjeka dozvoljeni su i ni jedna njena vrsta ne može se zabraniti bez potpuno jasnog, posebnog i vjerodostojnog dokaza.

- Islam je pri klasifikaciji hrane na zabranjenu i dozvoljenu imao jasnu filozofiju koja je kompatibilna sa generalnom islamskom filozofijom šerijata. Zbog toga je od hrane dozvolio samo onu koja je čista, zdrava i korisna, a zabranio onu koja je nečista, nezdrava i štetna.

- Svaka hrana koja je čista po šerijatu ne znači i da je dozvoljena jer šerijatska čistoća i halal hrana nisu u kauzalnoj vezi.

- Ogavnost koja se osjeća prema nekoj hrani kao i običaj konzumiranja ili nekonzumiranja u nekim krajevima ne znače i njihovu zabranjenost ili dozvoljenost.

- Šerijatski način ishrane jedina je postojeća realna i prirodna alternativa koja može zdravlje savremenog čovjeka zaštiti od savremenog načina proizvodnje, potrošnje i konzumiranja hrana.

- Islam se kod vrednovanja stvari i propisivanja zakona povodi za prirodno ljudskim, moralnim i etičkim vrijednostima, za razliku od

112 Kasani, El-Bedai', 5/43; Hirši, Hašijetu-l-Hirši, 1/85; Remli, Nihajetu-l-muhtadž, 1/227; Ibn Kudame, El-Mugni, 11/89. 
savremenog materijaliziranog čovjeka koji se u svemu tome povodi samo za profitom i materijalnom dobiti.

\section{Literatura}

1. Ibn Abidin, Muhammed Emin, Hašijetu Reddu-l-muhtari 'alad-deri-l-muhtar, šerh Tenviri-l-ebsar, Mustafa el-Babi eHalebi, Kairo, drugo izdanje, 1386.h.g./ 1966.

2. El-Badži, Ebu-1-Velid Sulejman, El-Munteka, Šerhu-l-Muvetta, Mateb'atu-s-se'ade.

3. Bejheki, Ebu Bekr Ahmed b. Husejn, Es-Sunenu-l-kubra, prvo izdanje 1344. h. g. Medžlisu dairetu-l-me'arifi en-nizamijjeti, Hajder Abad, Indija.

4. Darekutni, Ali b. Omer, Senen, četvrto izdanje, 1986, 'Alemu1-kutub, Bejrut.

5. Darimi, Abdullah b. Abdurrahaman, Es-Sunen, prvo izdanje, 1996, Daru-1-kutubi-1-'ilijjeti.

6. Derdir, Ebu Berekat Sejjidi Ahmed, Eš- ̌́derhu-l-kebir, štampan sa Hašijom od Dusukija, Daru-l-fikr.

7. Dusuki, Šemsuddin Šejh, Hašijetu Dusuki 'ala šerhil kebir, Daru-l-fikr.

8. Ebu Davud, Sulejman b. el-Eš'as, Ee-Sunen, Matbe'atu 'Izzet Ubejd De'aas.

9. Elusi, Šihabuddin es-Sejjid Mahmud, Ruhul me'ani, Tab'atu-1munirijetu.

10. Ibn Hadžer, Ahmed b. Ali b. Hadžer, Fethu-l-Bari, elMektebetu-s-selefijjetu.

11. Hejtemi, Šihabuddin Ahmed b. Hadžer, Tuhfetul muhtadž 'ala havaši-š-Šervani ve Kasim el-'Ubadi, Daru sadir, Bejrut.

12. Ibn Hadžer el-'Askalani, Telhisu-l-habir fi tehridži ehadisi-rRafi'i-l-kabir, Šeriketu-t-tiba'ati-l-fennijjti-l-muttehide.

13. El-Hirši, Abdullah b. Muhammed, Hašijetu-l-Hirši 'ala Muhtesari-l-halil, Daru sadir, Bejrut.

14. El-Hattab, Muhammed b. Abdurrahman, Mevahibu-l-Dželil Šerhu Muhteseru-l-Halil, prvo izdanje, 1978, Daru-l-fikr, Bejrut.

15. Ibn Hazm, Ebu Muhammed ali b. Ahmed, El-Muhalla bi-lasar, Daru-l-kutubi-l-'ilmijjeti, Bejrut, 1988. 
16. Kasani, 'Alauddin b. Mes'ud, Bedai'u-s-sanai'u fi tertibi-ššarai', Šeriketu-1-matbu'ati-1-'ilmijjeti, Egipat, prvo izdanje, 1327.h.g.

17. Ibn Kudame, Muvefekuddin Abdullah b. Ahmed, El-Mugni ve šerhu-l-kebir, Daru-1-menar, Kairo, treće izdanje, 1367.h.g.

18. Ibn Madže, Muhammed b. Jezid el-Kazvini, Sunen, Matbe'atu Isa el-Halebi.

19. Malik, Enes b. Malik, El-Muvetta, Daru ihjai-l-kutubi-l-'arabi, Kairo.

20. Mubarekfuri, Muhammed Abdurrahman b. Abdurrahim, Tuhfetu-l-ahvezi šerh Džami'u-t-Tirmizi, treće izdanje, 1987, Mektbetu Ibn Tejmijje, Kairo.

21. Muslim, Ibn Hadždžadž el-Kušejri en-Nejsaburi, es-Sahihu, Matbe'atu Isa el-Halebi.

22. Muvefekuddin b. Kudame el-Makdisi, El-Mukni', Izdanje kralja Fehda, Rijad.

23. Rehibani, Muhammed b. Ebi-l-Abbas, Matelibu 'uli-n-nuha fi šerhi-l-gajeti-l-munteha, Mektebu-1-islami, Damask, 1961.

24. Er-Remli, Šemsuddin Muhammed, Nihajetu-l-muhtadžd ila šerhi-l-minhadž, Nešru-1-mektebetu-1-islami.

25. Ibn Rušd, Ebu-1-Velid el-Kurtubi, Bidajetu-l-mudžtehid ve nihajetu-l-muktesid, Nešru mektebati-l-kulijjati-l-ezherije, 1386. h. g./1966.

26. Eš-Šerbini, Muhammed el-Hatib, Mugnil muhtadž ila m'arifeti me'ani elfazi-l-Minhadž, Matbe'atu Mustafa Halebi.

27. Ševkani, Muhammed, b. Ali, Nejlu-l-evtar, Šerhu Munteka-lahbar, Daru-1-džej1, 1973, Bejrut.

28. Tahavi, Muškilu-l-asar, Dairetu-1-me'arifi-n-nizamijje.

29. Tirmizi, Ebu Isa, Muhammed b. Isa, Es-Sunen, Daru-1-hadis.

30. Vizaretu-l-evkafi ve-š-šu'uni-1-islamijjeti, El-Mevsu'atu-lfikhejjetu, četvrto izdanje, 1993, Kuvajt.

31. Zejle'i, Fahruddin 'Usman b. Ali, Nasbu-r-rajeti fi tahridži-lehadisi-l-hidaje, Mateb'atu Medžlisu-l-'ilmi.

32. Ez-Zejle'i, Fahruddin 'Usman b. Ali, Tebjinu-l-hakaik, Šerh Kenzu-d-dekaik, Daru-1- me'arifi. 
PROF. DR. SULEJMAN TOPOLJAK, P.H.D.

\section{HUMAN DIET IN THE LIGHT OF SHARI'AH RULES AND INTENTIONS}

\section{SUMMARY}

This study elaborates one of the essential human questions. It tackles the issue of human diet in the light of Islamic rules and intentions. The aim of the study was to try to establish the fact that Islam is the universal system of living which is corroborated with the fact that its norm and rules did not disregard a single segment of human life. Then the study focused on the sources of human diet, whether of plant or animal origin, and they were counted thoroughly and each was tackled from the law's point of view. During the study a law status of many sources of food was corroborated with relevant evidence and unprejudiced discussion and objective selection of the most acceptable opinion.

The study also tried, wherever possible to offer basic or principle rules on ground of which in Islam is possible to differentiate between lawful and unlawful food.

In the end there is a conclusion that classification of food in Islam as lawful and unlawful is solely right of the creator. The reason is obvious, because he is the One who created man and only he knows which food is good and suitable and which bad and harmful. And general conclusion of this study is that the philosophy of Islamic diet is not biased on material profit and business, but it is primarily based on general advantage for human, preservation of his health and cosmic harmony of man and surrounding nature. 
الأستاذ الدكتور سليمان توبولياك

\section{التغذية في ضوء الأحكام و المقاصد الثرعية}

الملخص

يتتاول هذا البحث واحدة من أهم قضايا البشر، وهي فلسفة الغذاء البشري في ضوء الأحكام و المقاصد الثرعية. حاول البحث إثبات أن الإسلام نظام شامل للحياة البشرية مستدلاً على ذلك بأن أحكامه لم تهمل حتى أصغر جزئية في حياة البشر. ثم ركز البحث

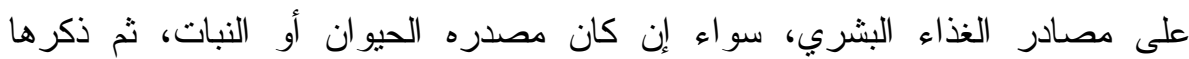
بالتقصيل وبيّن وضعها الشرعي. نم شرح تكييف شرعي لمعظم مصادر الغذاء، إضافة

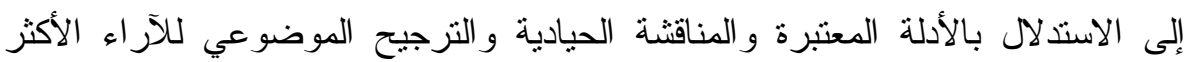
قبو لاً.

حاول البحث، قدر الاسنطاعة، أن يقدم القواعد الأساسية التي يمكن من خلالها

$$
\text { التعرف على الحلال و الحر ام. }
$$

أخيراً... لقد تم التوصل إلى استنتاج أن تصنيف الغذاء في الإسلام إلى الحلاص و الحر ام، قبل كل شيء، حق للمشرِع، وذلك انطلاقاً من الحقيقة البدهية أنه خلق الإنسان و أنه الوحيد يعلم ما هو الطعام المناسب والنافع للإنسان وما هو غير المناسب و الضـار . المحصلة العامة التي توصل إليها البحث هي أن فلسفة الغذاء في الإسلام لا تقوم و لا ولان تتطلق من مبدأ الربح المادي و إنما، وقبل كل شيء، من مصلحة البشر وحفظ ورعاية صحة الإنسان ونتاسق كوني بين الرجل و الطبيعة المحيطة به. 